\title{
EFFECT OF DIETS CONTAINING DIFFERENT LEVELS OF SUN DRIED MORINGA OLEIFERA LEAVES ON MILK YIELD, CHEMICAL COMPOSITION AND REPRODUCTIVE PERFORMANCE OF RABBIT DOES
}

\author{
A.M. Singer ${ }^{1}$; O. S. F. Khalil ${ }^{2}$; and Hoda Al-Zahar ${ }^{3}$ \\ ${ }^{1}$ Animal and Poultry Production Department, Faculty of Agriculture and Natural Resources, Aswan \\ University, Aswan, Egypt. \\ ${ }^{2}$ Dairy science and Technology Department, Faculty of Agriculture and Natural Resources, Aswan \\ University, Aswan, Egypt. \\ ${ }^{3}$ Dairy science Department, National Research Center, Dokki, Giza, Egypt.
}

(Received 26/6/2018, accepted $1 / 8$ /2018)

\section{SUMMARY}

$\mathrm{S}$ ixty Virgin New Zealand White Rabbit Does(VNZWRD) during three consecutive reproductive cycles, with average initial age of six months and weighing $2.98 \mathrm{~kg}$ and servicing for the first time at seven months were allotted to four experimental diets. Sun dried Moringa oleifera leaves replaced soybean meal by $0 \%\left(\mathrm{G}_{0 \%}\right), 25 \%\left(\mathrm{G}_{25 \%}\right), 50 \%\left(\mathrm{G}_{50 \%}\right)$ and $75 \%\left(\mathrm{G}_{75 \%}\right)$. Results showed non significant differences in the total feed intake(FI) and average body weight does on the different groups. The $\mathrm{G}_{75 \%}$ does had the highest FI (183.20 g/day) followed by $\mathrm{G}_{25 \%}(173.80 \mathrm{~g} /$ day $), \mathrm{G}_{50 \%}\left(169.80 \mathrm{~g} /\right.$ day) whereas $\mathrm{G}_{0 \%}$ does had the lowest (168.40 g/day).There were significant differences in the litter size at birth (LSB) of does on the different groups .The $\mathrm{G}_{75 \%}$ does had the highest litter size at birth of(7.866) followed by $\mathrm{G}_{50 \%}(7.622)$ and $\mathrm{G}_{25 \%}(7.377)$, while $\mathrm{G}_{0 \%}$ does had the lowest (6.422).Both litter weight at birth and litter weight at weaning were highest in $\mathrm{G}_{75 \%}$ $(392.44$ and $3162.73 \mathrm{~g})$, respectively with significant $(\mathrm{p}<0.01)$ different in litter weight at weaning across all levels of SDMOL. There were significant differences $(\mathrm{p}<0.01)$ in average milk yield during 21 across. Milk yield was higher in $\mathrm{G}_{75 \%}(2095.02 \mathrm{~g})$ followed by $\mathrm{G}_{50 \%}(2048.82 \mathrm{~g}), \mathrm{G}_{25 \%}(2019.33 \mathrm{~g})$,while $\mathrm{G}_{0 \%}$ does had the lowest $(1957.22 \mathrm{~g})(\mathrm{p}<0.01)$.It can be concluded that sun dried Moringa oleifera leaves can be used as additives without adverse effect on the reproductive performance of and milk yield of does rabbits.

Keywords: sun dried Moringa oleifera leaves, Virgin doe's rabbits, Reproductive performance and Milk yield.

\section{NTRODUCTION}

Moringa oleifera is known as "the mother's best friend" due to its uses to increase nursing mothers' milk production (Valdivié, et al.,2017 that may be attributed to $\mathrm{Cu}$ and $\mathrm{Zn}$, which are essential in increasing the rate of pregnant female milk production (Valkovic, 1975). Moringa leaves have high contribution toward the increasing of growth and organism level of health mainly to increase rural community health, supplement for pregnant women and to recover type 2 diabetes (Markus et al.,2017).Moringa leaves are sometimes used mostly to tackle problems encountered primarily related to the adequacy of protein. The galactogogue effect of moringa leaves meals increase milk production as a result of increasing of prolactin secretion (Markus et al. (2017). Leaves are very nutritious and rich in protein,essential amino acids, vitamins A, B and C, and minerals. They are highly recommended for pregnant and nursing mothers as well as young children (FAO, 2014). They are generally cooked (boiled, pan-fried) and eaten like spinach or put in soups and sauces. Moringa leaves are also eaten as a salad or dried and ground to make a very nutritious leaf powder. Moringa leaf powder is used to aid the restoration of infants suffering from malnutrition. Many trials have assessed the nutritive value of moringa leaf meal, for growing rabbits, as a potential replacement for soybean meal (Nuhu, 2010; Ewuola et al., 2012a; Odetola et al., 2012; Owen et al., 2013), ground nut cake (Adeniji and lawa., 2012; Alemede et al., 2014), wheat offal (Vantsawa and Dramola., 2014), or maize bran plus soybean meal (Abu et al.,2013). Inclusion rates in such diets ranged between 10 and 15\%. These trials generally 
concluded that moringa leaf meal can be used safely in rabbit feeding, with no reduction in growth rate, feed efficiency, and slaughter yield or blood parameters. However, moringa leaf meal has been linked to a slight but significant reduction of serum glucose and serum cholesterol concentration (Rajeshwari et al., 2008; Ewuola et al., 2012b). In some trials, moringa leaf meal was included successfully at 30\% (Dahouda et al., 2013), and up to 40\% of the diet (Safwat et al., 2014b). Ayodele et al., 2014 found that substitution for soybean meal protein by Moringa leaf meal improved performance breeding does rabbit.The present work was conducted to study the effect of replacing different levels of soybean meal by moringa leaves on productive and reproductive performance of rabbit does.

\section{MATERIALS AND METHODS}

\section{Experimental site and formulated diets}

The present experiment was carried out at the private farm of Kaluobia governorate, Egypt during January (2017). The chemical analysis was conducted at the laboratories of the Faculty of Agriculture and Natural Resources - Aswan University. The objective of this experiment was to study the effect of replacing 25,50 and $75 \%$ of soybean meal in does rabbit diets by sun dried Moringa oleifera leaves powder (SDMOLP).

\section{Animals}

Sixty Virgin New Zealand White Rabbit Does (VNZWRD) were used, during three consecutive reproductive cycles, with average initial age of six months and weighing $2.98 \mathrm{~kg}$ and servicing for the first time at seven months.

Rabbit does were housed individually in galvanized wire cages and were randomly assigned to 4 experimental groups (fifteen per each group), on the basis of live body weight and age .Each experimental group was fed ad libitum on one of the four following diets .

$\mathrm{G}_{0 \%}$ : pelleted complete diet formulated in the farm where the main source of protein was soy bean meal and served as control group.

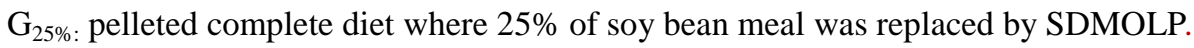

$\mathrm{G}_{50 \% \text { : }}$ pelleted complete diet where $50 \%$ of soy bean meal was replaced by SDMOLP.

$\mathrm{G}_{75 \%}$ : pelleted complete diet where $75 \%$ of soy bean meal were replaced by SDMOLP .

Does were fed rations ad libitum intake and clean water was available for all rabbits by nipple drinker all time. The experimental period lasted for 96 days.

All Does were weighed at the end of the every one reproductive cycle, using digital scale, for monitoring of weight change and feed conversion. Initial body weights were recorded. Changing does weigh calculated at the end of the every one reproductive cycle. Average daily feed intake (ADFI) by individual does was estimated by summing the monthly intake and dividing by the number of days of the month. Ingredients and chemical composition of the experimental diets are reported in Table (1). Feed offered and feed refused were recorded daily.

\section{Time service:}

Prior to first servicing, does were allotted in four groups and fed the experimental diets during 30 days. Females were serviced in the morning by taking the females to the male's cycling cage. On the $2^{\text {nd }}$ day of kindling, does were serviced again. Thereby starting a new reproductive cycle. Does were tested ventrally two weeks after mating, and those that negative were remitting again. Four days before Kindling, nest boxes were placed in front does cages, where they remained until kits were 26 days old .During the time that nest boxes remained in front does cages .At the three days after kindling, daily inspections were mad to maintain adequate conditions during the physiological stage. The litters were weaned at 26 day in the three parities.

\section{Measurements, Sample collection for laboratory analyses}

Rabbit milk yield and composition:

Milk production was estimated daily from 1 to 21 day of age of the litter using the weight -suckle-weigh 
methods (Lukefahr et al., 1983). Milk samples were collected $(10 \mathrm{ml})$ from five does each group on day $21^{\text {st }}$ using 'home made air vacuum pump' from most nipples of mammary gland. Milk samples were analyzed for fat, protein and lactose by infrared spectrophotometry (Foos120 Milko-Scan,Foss Q3183 electric, Hiller0d, Denemark).

Table (1): Ingredients and chemical composition of the experimental rations (DM \%).

\begin{tabular}{lcccc}
\hline Item & \multicolumn{3}{c}{ Levels SDMOL (\% of dietary DM) } \\
\hline Ingredients (DM \%) & ${ }^{1} \mathrm{G}_{0 \%}$ & ${ }^{2} \mathrm{G}_{25 \%}$ & ${ }^{3} \mathrm{G}_{50 \%}$ & ${ }^{4} \mathrm{G}_{75 \%}$ \\
Alfalfa hay & 30 & 30 & 30 & 30 \\
yellow corn & 11.2 & 11.2 & 11.2 & 11.2 \\
Barley & 20 & 20 & 20 & 20 \\
Soybean meal & 12 & 9 & 6 & 3 \\
SDMOLP & 0 & 3 & 6 & 9 \\
Wheat bran & 25 & 25 & 25 & 25 \\
Limestone & 0.7 & 0.7 & 0.7 & 0.7 \\
Permix & 0.3 & 0.3 & 0.3 & 0.3 \\
Salt food & 0.3 & 0.3 & 0.3 & 0.3 \\
Dicalcium Phosphate & 0.5 & 0.5 & 0.5 & 0.5 \\
Total & 100 & 100 & 100 & 100 \\
Cost1kg diets L.E & 4.00 & 5.68 & 7.36 & 9.04 \\
Calculated diets composition, \% & & & & \\
CP\% & 17.286 & 16.794 & 16.302 & 15.81 \\
EE\% & 4.463 & 4.685 & 4.907 & 5.129 \\
CF\% & 12.551 & 12.828 & 13.105 & 13.383 \\
\hline SDMOLP Sum Dried Moringa & & &
\end{tabular}

SDMOLP = Sun Dried Moringa oleifera Leaves powder.

${ }^{l}=$ control diet,${ }^{2}=25 \%$ SDMOLP,${ }^{3}=50 \%$ SDMOLP and ${ }^{4}=75 \%$ SDMOLP

\section{Feed conversion ratio}

This was calculated according to lyayi et al.,(2003) as following:

Feed conversion ratio $=\mathrm{FI}(\mathrm{g}) / \mathrm{LWW}(\mathrm{g})$.

Where: FI $(\mathrm{g})=$ Feed intake $(\mathrm{g})$

LWW $(\mathrm{g})=$ Litter weight weaning $(\mathrm{g})$

\section{Statistical Analysis}

All data were analysed according to complete randomized design SAS using the PROC MIXED procedure of SAS (2004). The statistical model was: $Y_{i j}=\mu+G_{i}+C_{j}+E_{i j}$, in which $Y_{i j}$ is the dependent variable, $\mu$ is the overall mean, $G_{i}$ is the fixed effect of groups ( $i=1,2,3$ and 4$), C_{j}$ is the random effect of animal within group, and $\mathrm{E}_{\mathrm{ij}}$ is the residual error. Group means were computed with the LSMEANS option.

\section{RESULTS AND DISCUSSION}

\section{Chemical composition}

As shown in Table(2), chemical analysis of SDMOL compared with SBM revealed that CP was (27.20 vs 43.60 ), CF ( 11.50 vs 6.61),EE(7.40 vs 2.55), NFE (46.91 vs36.64) and ash (9.60 vs 7.75). Zarkadas et al., (1995) observed that the Moringa oleifera has high biological value protein contain the most essential amino acids in additional it has higher concentration than the one recommended by FAO and WHO(1991) mentioned in the feed reference that is soybeans. Aye and Adegun(2013) showed that Moringa oleifera leaves meal contains DM(93.63), ash(7.96), $\mathrm{CP}(22.23), \mathrm{CF}(6.77), \mathrm{EE}(6.41)$ and NFE(40.28).Also, Ojo and Abdurahman(2017) found that Moringa oleifera contained DM(91.78), CP(28.43), EE (6.40), CF(9.15),total ash(9.09) and NFE(46.93). These variations in chemical composition of Moringa oleifera may attributed to many factors (location and time of harvesting of plants). 
Singer et al.

Table (2 ) :Chemical Composition of soybean meal and sun dried Morina Oleifera leaves on DM basis.

\begin{tabular}{llllllll}
\hline Item & DM\% & OM\% & CP\% & EE\% & CF\% & NFE\% & Ash\% \\
\hline Soybean meal & 89.4 & 92.25 & 43.60 & 2.55 & 6.61 & 39.49 & 7.75 \\
Sun dried Moringa Oleifera & 93.01 & 90.40 & 27.2 & 7.40 & 11.50 & 44.3 & 9.60
\end{tabular}

$D M=$ dry matter $; O M=$ organic matter CP = crude protein $C F=$ crude fiber EE = ether extract ;FE = nitrogen free extract.

\section{Feed intake and body weight changes}

Data of Table (3) showed that feed intake of does fed on different levels of SDMOL was non significant more than does fed the control diet. The does fed the $G_{75 \%}$ diet showed the greatest feed intake (183.20 $\mathrm{g} /$ day) compared the $\mathrm{G}_{0 \%}$ diet (168.40 $\mathrm{g} /$ day). On the other hand feed intake was increase gradually in all treatments by increase in doe weight during the three kindling (from the first Kindling to the third kindling) than that of does receiving the $\mathrm{G}_{0 \%}$ diet.

Table (3): Effect of SDMOL on productive performance.

\begin{tabular}{|c|c|c|c|c|}
\hline \multirow{2}{*}{$\begin{array}{l}\text { Item } \\
1^{\text {st }} \text { Parturition }\end{array}$} & \multicolumn{4}{|c|}{ Levels SDMOL } \\
\hline & $\mathrm{G}_{0 \%}$ & $\mathrm{G}_{25 \%}$ & $\mathrm{G}_{50 \%}$ & $\mathrm{G}_{75 \%}$ \\
\hline WDI(kg) & 3.0 & 2.96 & 3.0 & 2.96 \\
\hline $\mathrm{WDK}_{1}(\mathrm{~kg})$ & 3.22 & 3.10 & 3.18 & 3.24 \\
\hline $\mathrm{CBD}_{1}(\mathrm{~kg})$ & 0.22 & 0.14 & 0.18 & 0.28 \\
\hline $\mathrm{FIDD}_{1}(\mathrm{~g} /$ day $)$ & 168.4 & 173.8 & 169.8 & 183.2 \\
\hline \multicolumn{5}{|l|}{$2^{\text {nd }}$ Parturition } \\
\hline $\mathrm{WDK}_{2}(\mathrm{~kg})$ & 3.34 & 3.42 & 3.50 & 3.64 \\
\hline $\mathrm{CBD}_{2} \quad(\mathrm{~kg})$ & 0.16 & 0.32 & 0.40 & 0.40 \\
\hline $\mathrm{FIDD}_{2}(\mathrm{~g} /$ day $)$ & 224.2 & 219.80 & 226.40 & 230.60 \\
\hline \multicolumn{5}{|l|}{$3^{\text {rd }}$ Parturition } \\
\hline $\mathrm{WDK}_{3}(\mathrm{~kg})$ & 3.30 & 3.70 & 3.68 & 3.76 \\
\hline $\mathrm{CBD}_{3}(\mathrm{~kg})$ & 0.080 & 0.28 & 0.22 & 0.18 \\
\hline $\mathrm{FIDD}_{3}$ (g/day) & 226.4 & 258.60 & 248.2 & 258.0 \\
\hline
\end{tabular}

Where:
$W D I=$ Weight does initial $\quad W D K_{1}=$ Weight does $1^{\text {st }}$ kindling $\quad W D K_{2}=$ Weight does $2^{\text {nd }}$ kindling $W D K_{3}=$ Weight does $3^{\text {rd }}$ kindling $\quad C B D_{1}=$ Change bodydoes $1^{\text {st }}$ kindling $\quad C B D_{2}=$ Change body does $2^{\text {nd }}$ kindling $\mathrm{CBD}_{3}=$ Change body does $3^{\text {rd }}$ kindling $\quad F I D D_{1}=$ Feed intake daily does $1^{\text {st }}$ kindling $F I D D_{2}=$ Feed intake daily does $2^{\text {nd }}$ kindling $\quad F I D D_{3}=$ Feed intake daily does $3^{\text {rd }}$ kindling

Data of Table (3) showed non significant difference in initial body weight of does (in the mating weights that, ranged between 2.96 and $3.0 \mathrm{~kg}$. Changes of does body weight during the first weaning parity, second weaning parity and third weaning parity did not differ between the different levels of SDMOL. That means no negative effect of moringa on body weight changes of rabbit does.

\section{Litter size}

Data in Table(4) showed that average litter size at birth ,litter size a live, litter weight at birth and litter weight at weaning for the different four treatments studied as affected by treatment varied from 7.866 vs

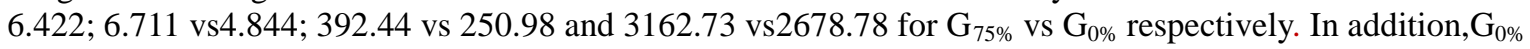
gave significantly (P> 0.01)smallest litter size at birth and litter weight weaning compared with $\mathrm{G}_{75 \%}$. These results agreed with those obtained by Khalil (1998), and Abokhadiga,( 2004). The number of dead kits from birth to weaning per reproductive cycle were the highest in the $\mathrm{G}_{0 \%}$ and $\mathrm{G}_{25 \%}$ (1.577)compared with (1.156) $\mathrm{G}_{75 \%}$ possibly as a result of lowest feed intake $\mathrm{G}_{0 \%}$ diet , consequently , the smaller litter size of G0\% was due to insufficient diet to provide the necessary amount of producing milk in $\mathrm{G}_{0 \%}$.Also, data showed that does receiving the $\mathrm{G}_{75 \%}$ weaned larger and heavier litter at $21^{\text {st }}$ day. These results agree with those of Gonzalez and Herrera (2012) and Caro (2014). 
Table (4):Effect of SDMOL on rabbit reproductive performance of does.

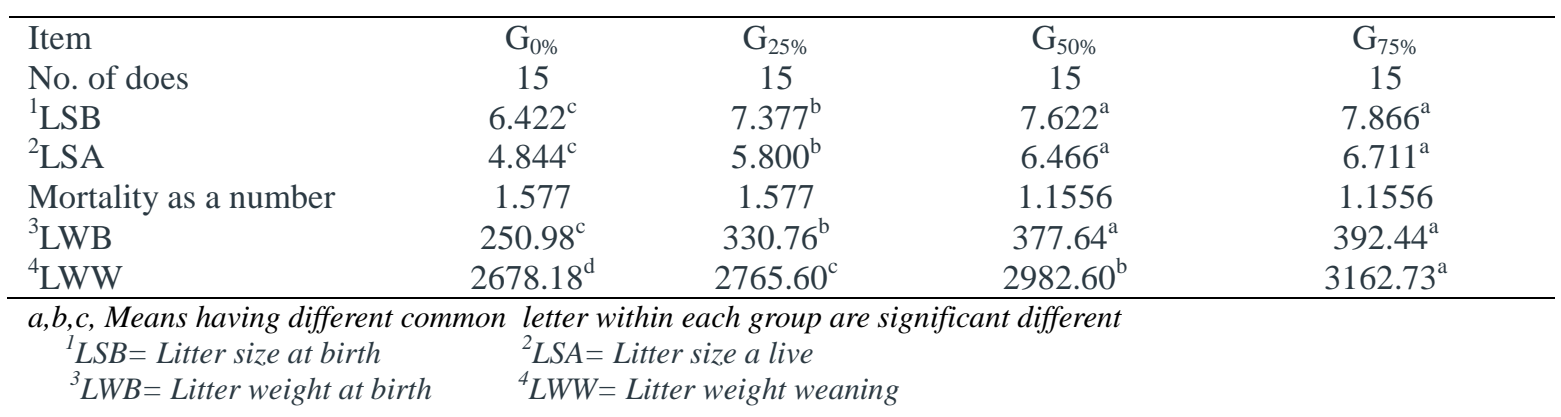

The present results show that the does received the different levels of SDMOL(25,50 and 75\%) produced significantly heavier kits weight at birth and at weaning than those of control treatment . These results agree with Odeyinka et al. (2008)who found that does received high level of Moringa oleifera (M100) had higher weight at weaning than does received low level of Moringa oleifera(M25). The present results indicate that replacing $75 \%$ of soya protein in rabbit's ration by SDMOL increased litter weight at weaning by $18.09 \%$ as compared with $\mathrm{G}_{0 \%}$ group. This enhancement in litter weight at weaning may be due to the effects of SDMOL on metabolic rate or improving efficiency in conversion of milk to body gains in litters (Never, (2018).

\section{Milk yield and composition}

Data in Table (5) showed that milk yield was significantly increased as the level of SDMO was increased. The greatest milk yield was observed in does fed the $G_{75 \%}$ compared to the $G_{0 \%}$. These results agree with Markus et al.,( 2017) who found that the higher level of moringa oliefera leaves meal increased $(\mathrm{P}<0.05)$ prolactin hormone concentration followed by increasing milk production. Also, Kholif et al.,

Table (5): Effect of SDMOL on milk yield and composition of rabbit does.

\begin{tabular}{|c|c|c|c|c|}
\hline Item & $\mathrm{G}_{0 \%}$ & $\mathrm{G}_{25 \%}$ & $\mathrm{G}_{50 \%}$ & $\mathrm{G}_{75 \%}$ \\
\hline Milk yield in $1^{\text {st }}$ Kindling(g/21 days $)$ & 1807.27 & 1865.33 & 1881.13 & 1949.87 \\
\hline Fat $\%$ & 12.86 & 12.78 & 12.78 & 12.74 \\
\hline Protein $\%$ & 10.222 & 10.426 & 11.644 & 12.986 \\
\hline Ash \% & $2.08 \mathrm{c}$ & $2.26 \mathrm{~b}$ & $2.52 \mathrm{a}$ & $2.38 \mathrm{ab}$ \\
\hline Lactose \% & 1.91 & 1.776 & 1.848 & 1.750 \\
\hline Milk yield in $2^{\text {nd }} \operatorname{Kindling}(\mathrm{g} / 21$ days $)$ & 1884.93 & 1919.33 & 1961.80 & 1962.93 \\
\hline Fat $\%$ & 12.86 & 12.76 & 12.77 & 11.9 \\
\hline Protein $\%$ & 10.66 & 10.51 & 12.67 & 13.18 \\
\hline Ash \% & 2.08 & 2.26 & 2.52 & 2.38 \\
\hline Lactose \% & 1.91 & 1.8 & 1.84 & 1.87 \\
\hline Milk yield in $3^{\text {rd }} \operatorname{Kindling}(\mathrm{g} / 21$ days $)$ & 2179.47 & 2273.33 & 2303.53 & 2372.27 \\
\hline Fat $\%$ & 12.84 & 12.72 & 11.80 & 11.57 \\
\hline Protein $\%$ & 10.66 & 10.51 & 12.67 & 13.18 \\
\hline Ash \% & 2.22 & 2.26 & 2.22 & 2.50 \\
\hline Lactose $\%$ & 1.91 & 1.87 & 1.84 & 1.80 \\
\hline Over all means of Milk yield ( $\mathrm{g} / 21$ days) & $1957.722^{\mathrm{d}}$ & $2019.33^{c}$ & $2048.82^{b}$ & $2095.02^{\mathrm{a}}$ \\
\hline Over all means of Fat $\%$ & $12.849^{\mathrm{a}}$ & $12.756^{\mathrm{a}}$ & $12.453^{\mathrm{b}}$ & $12.072^{\mathrm{c}}$ \\
\hline Over all means of Protein $\%$ & $10.417^{\mathrm{c}}$ & $10.712^{c}$ & $12.189^{\mathrm{b}}$ & $13.174^{\mathrm{a}}$ \\
\hline Over all means of Ash\% & $2.140^{\mathrm{c}}$ & $2.306^{\mathrm{b}}$ & $2.36^{\mathrm{b}}$ & $2.460^{\mathrm{a}}$ \\
\hline Over all means of Lactose $\%$ & $1.910^{\mathrm{a}}$ & $1.818^{\mathrm{b}}$ & $1.845^{\mathrm{a}}$ & $1.809^{\mathrm{b}}$ \\
\hline
\end{tabular}

$a, b, c$, Means having different common Letter within each group are significant different.

(2015) explained the increased milk production as a result of the increased feed intake .In addition overall mean of ash was increased by $14.953 \%$ in $\mathrm{G}_{75 \%}$. Overall mean of lactose was decreased by 5.287 in $\mathrm{G}_{75 \%}$. The same trend was observed for milk protein content which was increased by $26.46 \%$ while milk fat 
content was decreased by $6.047 \%$,respectively .Rabbit milk composition varies depending on many factors, such as genetically (breeds ,age ,lactation stage and number of pups and environmentally ( nutrition , external parasites and heat)(Lukafahr et al.,1983).Data presented in Table (5) showed that milk yield, during the three kindling was significantly higher $(\mathrm{p}<0.01)$ for does fed the different levels of SDMOL than that does fed control diet .The over all of milk yield were $1957,219,2048$ and 2071 , respectively for $\mathrm{G}_{0 \%}, \mathrm{G}_{25 \%}$, $\mathrm{G}_{50 \%}$ and $\mathrm{G}_{75 \%}$.

The total milk production obtained in 21 days with does received $\mathrm{G}_{75 \%}$ was a little bit lower than that described by Khalil (1998) in Egypt for the Baladi red(2150 g) and the Baladi black (2180 g). It was lower than the $2640 \mathrm{~g}$ described by the same author for the Giza white, but clearly lower than the $3567 \mathrm{~g}$ observed by Mohamed and SzendrÖ (1992) for litters of 6 kits in a Californian line selected in Hungary. This relatively low milk production can be related to the relatively small adult weight $(3.0 \mathrm{~kg})$. Significant differences were found in the content of milk fat, protein and lactose.

\section{Effect of parites on milk yield}

Results of milk yield recorded during the third parity (Table 5) showed higher in milk yield compared to the second and first parites however, the second parity was better than the first parity. This increase may be due to the cumulative effect of feeding the sun dried Moringa oleifera leaves.Tuma et al., (2010) found that parity order affected service number of pregnancy and litter weight at 21 days followed by increase in milk yield. The results in (Table5) showed that parities had a positive influence $(\mathrm{p}<0.01)$ on both milk yield and their chemical composition. Also, over all means of milk yield and protein percentage were the highest in $\mathrm{G}_{75 \%}$ compared to $\mathrm{G}_{25 \%}$. These results are in agreement with the finding of Khalil(1998).

\section{Feed conversion}

Data in Table (6) showed that Feed conversion was better in treated groups than control group during the three kindling. $\mathrm{G}_{75 \%}$ recorded the best value(1.840) followed by $\mathrm{G}_{50 \%}$ (1.872)then $\mathrm{G}_{25 \%}(1.943)$, while $\mathrm{G}_{0 \%}$ recorded the worest value (1.994 (FI g/LWW g). Although the overall means of total feed intake( $\mathrm{kg} / \mathrm{doe})$ in treated groups were higher, the overall means of feed conversion in treated groups were better than the control group in order to increase the number of kids treated groups. The higher number kids and best feed conversion rations were obtained in does fed rations contained SDMOL. Present data show that the does feed $\mathrm{G}_{75 \%}$ were more efficient $\left(\mathrm{p}<0.01\right.$ )compared with those fed $\mathrm{G}_{0 \%}$ in converting feed into milk during the three weeks post-partum period .

Table (6): Feed intake and feed conversion of rabbits does fed diets containing $0,25,50$ and75\% SDMOL.

\begin{tabular}{lcccc}
\hline Item & $\mathrm{G}_{0 \%}$ & $\mathrm{G}_{25 \%}$ & $\mathrm{G}_{50 \%}$ & $\mathrm{G}_{75 \%}$ \\
\hline No. of animals & 15 & 15 & 15 & 15 \\
$1^{\text {st }}$ Total feed intake (kg/doe) (26days) & 4.378 & 4.518 & 4.414 & 4.763 \\
$1^{\text {st }}$ FID(g/doe/day) & 168.4 & 173.8 & 169.8 & 183.2 \\
Litter Weight Weaning(g) & 2476.07 & 2598.93 & 2907.07 & 3040.87 \\
$1^{\text {st }}$ Feed conversion ratio (FI g/LWW g) & 1.768 & 1.738 & 1.698 & 1.566 \\
$2^{\text {nd }}$ Total feed intake (kg/doe) (26days) & 5.829 & 5.714 & 5.886 & 5.995 \\
$2^{\text {nd }}$ FID(g/doe/day) & 224.2 & 219.8 & 226.4 & 230.6 \\
Litter Weight Weaning(g) & 2708.93 & 2771.2 & 2925.8 & 3106.07 \\
$2^{\text {nd }}$ Feed conversion ratio (FI g/LWW g) & 2.151 & 2.062 & 2.011 & 1.93 \\
$3^{\text {rd }}$ Total feed intake (kg/doe) (26 days) & 5.886 & 5.943 & 6.453 & 6.708 \\
$3^{\text {rd }}$ FID(g/doe/day) & 226.4 & 258.6 & 248.2 & 258.0 \\
Litter Weight Weaning(g) & 2851.33 & 2926.67 & 3114.93 & 3341.27 \\
$3^{\text {rd }}$ Feed conversion ratio (FI g/LWW g) & 2.063 & 2.031 & 2.071 & 2.006 \\
Over all means Total feed intake (kg/doe) & 5.364 & 5.391 & 5.584 & 5.822 \\
Over all means Litter Weight Weaning(g) & $2678.78^{\mathrm{d}}$ & $2765.60^{\mathrm{c}}$ & $2982.60^{\mathrm{b}}$ & $3162.73^{\mathrm{a}}$ \\
Over all means of Feed conversion ratio. & 1.994 & 1.943 & 1.872 & 1.840 \\
\hline
\end{tabular}

Where: a,b,c, Means having different common Letter within each group are significant different. $F I D=$ Feed intake daily. 


\section{CONCLUSION.}

Moringa oleifera leaves can be used as an alternate for conventional concentrate in the diet of rabbit does due to its high crude protein content. It is recommended that replacing $75 \%$ soybean meal Moringa oleifera leaves could be used as a source of protein supplement for rabbit does.

\section{REFFRENCES}

Abou Khadiga G. S. M. (2004). Performance of the Spanish synthetic line (V) and the local Baladi Black rabbits and their crosses under Egyptian conditions. M. Sc. Thesis, Faculty of Agriculture, Kafr ElSheikh, Tanta University, Egypt.

Abu, A.H.,T. Ahemen, ,P. Ikpechukwu.( 2013). Testicular morphometry and sperm quality of rabbit bucks fed graded levels of Moringa oleifera leaf meal (MOLM). Agrosearch, $13(1)$ : 49-56.

Adeniji, A. A.and M.Lawa. (2012). Effects of replacing groundnut cake with Moringa oleifera leaf meal in the diets of grower rabbits. Int. J. Mol. Vet. Res., 2 (3) : 8-13.

Alemede, I. C. ,E.A. Onyeji, D.N.Tsado,E.L.Shiawoya. (2014). Reproductive response of rabbit does to diets containing varying levels of horseradish (Moringa oleifera) leaf meal. J. Biol. Agric. Healthcare, 4 (19):62-68.

Aye PA,M.K.Adegum.(2013). Chemical Composition and some functional properties of Moringa, Leucaena and Gliricidia leaf meals. Agric. Biol. J. N. Am. 4(1): 71-77.

Ayodele, A. E. ,J.R.Adeola,A.T.Mayowa. (2014). Reproductive performance of rabbit does fed graded levels of Moringa oleifera leaf meal based diet. Int. J. Sci., 3 (3): 50-53.

Caro, y. (2014). Uso de la harina de forraje de moringa (Moringa oleifera var. Supergenius) en l'alimentación de conejos de ceba Nueva Zelandia Blanco. Mención Monogastricos Instituto de Ciencia Animal, Mayabeque, Cuba. 56 p.

Dahouda, M. ,S.Adjolohoun,M.Senou,S.S.Toleba,M.Abou,D.S.Vidjannagni,M. Kpodékon,A.K.I.Youssao. (2013). Effects of diets containing Moringa oleifera Lam leafl and commericial feed on rabbit (Oryctolagus cuniculus) growth performance and meat quality. Int. J. Biol. Chem. Sci., 7 (5): 18381852.

Ewuola, E. O. ,O.A.Jimoh, O.V.Atuma, O.D.Soipe. (2012a). Growth indices and apparent nutrient digestibility in rabbits fed graded levels of moringa (Moringa oleifera) leaf meal. Nigerian J. Anim. Sci., 14: 92-100.

Ewuola, E. O.,O.A.Jimoh, O.V.Atuma,O.D. Soipe. (2012b). Haematological and serum biochemical response of growing rabbits fed graded levels of Moringa oleifera leaf meal. Proc. 10 th World Rabbit Congress - September 3 - 6, 2012-Sharm El- Sheikh - Egypt, 679-683.

FAO, (2014). Moringa. Traditional Crop of the Month. FAO.

FAO/WHO(1991).Protein quality evaluation. Food and Agricultural Organization of the United Nations. Rome .

Iyayi, e. o.,o. oluwakemi, and m.odueso. (2003). response of some metabolic and biochemical indices in rabbitsfed varying levels of dietary cyanide.african journal of biomedical research, 6(1): 43-47

González, L.A. and C.E.Herrera. (2012).Inclusión de harina de hoja de Marango (Moringa oleifera) en la alimentación de conejos de engorde y su efecto en el comportamiento productivo.Requisito para obtener el título de licenciado en Zootecnia. Universidad Nacional Agraria.Managua, Nicaragua. 30 p.Journal of Applied Rabbit Research, 15, 708-716.

Khalil, M.H.(1998). Model for the description of rabbit genetic resources in Mediterranean countries. Application to the Egyptian breeds Giza White and Baladi.Mediterranean RabbitWorking group.41p.

Kholif, A.E.,G.A.Gouda,T.A.Morsy,A.Z.M.Salem,S.Lopez,A.M.Kholif.(2015). Moringa oliefera leaf meal 
as a protein source in lactating goat's diets:Feedintake ,digestability,ruminalfermentation,milk yield and composition, and its fatty acids profile. Small Ruminant Research 129:129-137.

Lukefahr S.D.,W.D.Hohenboken,P.R. Cheeke , N.M.Patton. (1983). Doe reproduction and preweaning litter performance of straightbred and crossbred rabbits. J. Anim. Sci., 57: 1090-1099.

Markus, M.K., Hendrawan S., Kusmartono ; Kuswanto (2017).Concentration of Progesterone and Prolactin Hormones and Milk Production of New Zealand White Rabbits Doe Fed Moringa Leaves Meal. Mediterranean Journal of Social Sciences MCSER Publishing, Rome-Italy. Vol 8 No 3.

Mohamed, M.M.A. and Zs Szendrö (1992). Studies on nursing and milk production of does and milk intake and suckling behaviour of their kits. 5th World Rabbit Congress, Moringa oleifera (moringa) in the feeding of non-ruminants.

Never, A.,(2018). Factors influencing does milk production and their implication for kit performance in rabbits. Scientific Journal of Animal Science : 7(1) 471-478

Nuhu, F., (2010). Effect of moringa leaf meal (MOLM) on nutrient digestibility, growth, carcass and blood indices of weaner rabbits. In: MSc. Thesis. Anim. Nutr., Kwame Nkrumah University, Kumasi (Ghana), 122 pp. M.Sc. Thesis (unpublished). Department of Animal Science Kwame Nkrumah. Faculty of Agriculture and Natural Resources.University of Science and Technology.

Odetola, O. M. ; O. O.Adetola.; T. I. Ijadunola.; O. Y. Adedeji. and O. A.Adu., (2012). Utilization of moringa (Moringa oleifera) leaves meal as a replacement for soya bean meal in rabbit's diets. Schol. J. Agric. Sci., 2 (12): 309-313.

Odeyinka S.M., O.J.Oyedele., T.O. Adeleke., J.A.Odedire.( 2008) Reproductive performance of rabbits fed Moringa oleifera as a replacement for centrosema pubescens. 9th World Rabbit Congress - June 10-13, Verona - Italy

Ojo, O.A. and K.O.Abdurahman (2017).Effect of Moringa oleifera Leaf Extract (Mole) on some Reproductive Parameters of Rabbits Reared in a Semi-Humid Environment. Global Journal of Science Frontier Research (D)Volume 17 Issue 4 Version 1.0 .

Owen, O. J. ; P. C. N. Alikwe.; I.A. Okidim. (2013). The economic potential of compounding rabbit diets with graded levels of Moringa oleifera leaf meal. J. Env. Issues Agric. in Dev. Countries, 5 (2): $34-40$

Rajeshwari,Y. B.; Y. S.Suhas. and N. C.Siddeswara., (2008). Effect of feeding Moringa oleifera tree leaves on blood parameters in broiler rabbits. 3rd Rabbit Congress of the Americas" Maringa, Parana, Brazil. August, 21-23, 2006. World Rabbit Sciences, 16, 38.

Safwat, A. M.; Sarmiento-Franco, L.; Santos-Ricalde, R.; D.Nieves, (2014b). Effect of dietary inclusion of Leucaena leucocephala or Moringa oleifera leaf meal on performance of growing rabbits. Trop. Anim. Health Prod., 46 (7): 1193-1198.

SAS (2004). SAS/STAT User's Guide: Version 9.1 in. SAS Institute Inc., Cary, NC.

Tůma.J., E.Tůmová and V. Valášek (2010).The effect of season and parity order on fertility of rabbit does and kit growth. Czech J. Anim. Sci., 55, (8): 330-336.USA

Valdivié.M., D. Bustamante, Y. Caro, L.M. Dihigo, J. Ly and L. Savón .(2017). Moringa oleifera (moringa) in the feeding of non-ruminants. Chapter 8. January 2017.

Valkovic.V. V., 1975. Trace Element Analysis, vol. 5, Taylor and Francis, London, UK; RiceUniversity, Houston, Tex, USA.

Vantsawa, P. A.; A.Daramola ., (2014). The effect of Moringa oleifera leaf meal (MOLM) on the hematological parameters and the cholesterol level of rabbits. Am. J. Biol. Chem. Pharmaceut. Sci., $2(3): 1-6$.

Zarkadas,C.G., Ziran,TY.U., and Burrows,V.D.(1995) Protein quality of three new Canadian -developed naked cat cultivars using amino acid composition data. J. Agric. Food Chem., 43:415-421. 
تأثير العلاثق المحتوية علي مستويات مختلفة من أوراق المورينجا المجفة شمسياً علي محصول لبن الارانب والاداء الانتاجي المين

$$
\begin{aligned}
& \text { 3عبدالله منصور سنجر1 و اسامه صفوت فوزي خليل2 و هدي الزهار3 } 3
\end{aligned}
$$

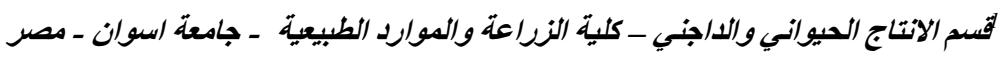

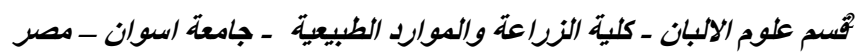

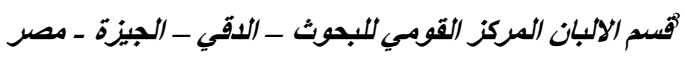

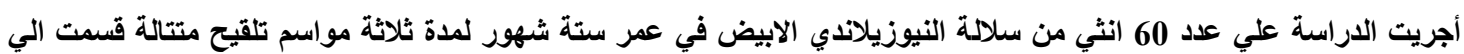

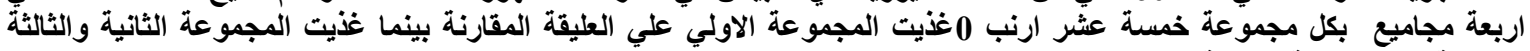

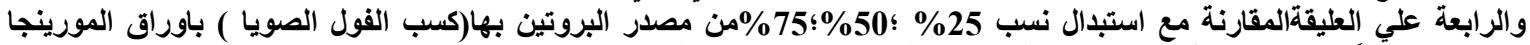

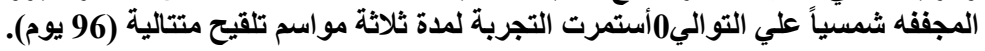

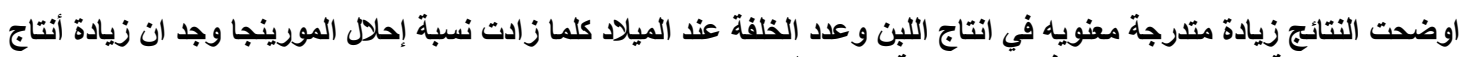
اللبن تبعه زيادة معنوية عند مستوي 1\% 1 في وزين الخلفة عند الفطام.

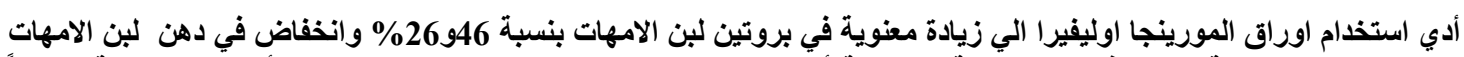

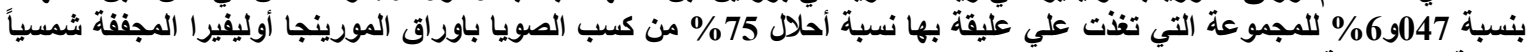
مقارنة بالمجموعة الكنترول.

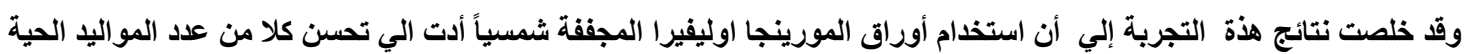

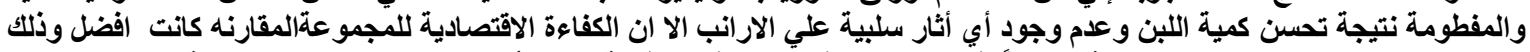

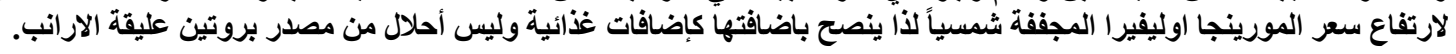

